\title{
Comparison of Sandy Soils Suppressive or Conducive to Ectoparasitic Nematode Damage on Sugarcane
}

\author{
Delphine Rimé, Sylvie Nazaret, François Gourbière, Patrice Cadet, and Yvan Moënne-Loccoz
}

First and fourth authors: SASEX and IRD, Private Bag XO2, Mount Edgecombe, 4300 KwaZulu Natal, South Africa; and first, second, third, and fifth authors: UMR CNRS 5557 Ecologie Microbienne, Université Claude Bernard (Lyon 1), 43 bd du 11 Novembre, F-69622 Villeurbanne, France.

Accepted for publication 16 May 2003.

\begin{abstract}
Rimé, D., Nazaret, S., Gourbière, F., Cadet, P., and Moënne-Loccoz, Y. 2003. Comparison of sandy soils suppressive or conducive to ectoparasitic nematode damage on sugarcane. Phytopathology 93:1437-1444.

Two South African sandy soils, one suppressive and the other conducive to ectoparasitic nematode damage on monoculture sugarcane, were compared. Analysis of field transects indicated that the suppressive soil displayed a comparatively higher population of the weak ectoparasite Helicotylenchus dihystera, whose predominance among ectoparasitic nematodes is known to limit yield loss caused by more virulent phytonematodes. Soil type was identical at both sites (entisols), but the suppressive soil had a higher organic matter content and a lower $\mathrm{pH}$,

climatic differences between the two field sites were unlikely to be responsible for the suppressive or conducive status of the soils, as shown in a greenhouse experiment. The two soils exhibited a bacterial community of the same size but with different genetic structures, as indicated by automated ribosomal intergenic spacer analysis (RISA). The number of culturable fluorescent pseudomonads was higher for the conducive soil, probably because extensive root damage caused by ectoparasitic nematodes favored proliferation of these bacteria. This study shows that apparently small differences in soil composition between fields located in the same climatic area and managed similarly can translate into contrasted nematode communities, ectoparasitic nematode damage levels, and sugarcane yields.
\end{abstract} which correlated with $H$. dihystera population data. In contrast, micro-
The soil ecosystem harbors a diverse community of free-living (saprophagous and bacterivorous) and parasitic nematodes, and over 200 different nematode species can be found at certain field sites (43). Phytoparasitic nematodes cause considerable damage to crops worldwide. Sugarcane is the target of many ectoparasitic and endoparasitic nematodes, and their effect on yield is significant $(1,32)$. In South Africa alone, sugarcane loss caused by phytoparasitic nematodes is estimated to exceed $10^{6}$ metric tons (t) of cane per year (32).

The negative effect of phytoparasitic nematodes varies depending on the nematode genus or species. In the case of ectoparasites of sugarcane, Helicotylenchus dihystera is less harmful than Xiphinema elongatum or Paratrichodorus minor. Therefore, it can be expected that damage severity in situ will be determined, to a large extent, by the combination of species of phytoparasitic nematodes present and their population levels $(2,41)$. This possibility is suggested by the comparison of sugarcane cultivation on sandy soils in West and South Africa, where nematode attacks on ratoon cane and subsequent crop loss are due mainly to ectoparasitic nematodes (32). These nematodes feed exclusively on roots, and most of their life cycle takes place in the rhizosphere. The ectoparasites $X$. elongatum and Paratrichodorus minor cause significant damage to ratoon cane roots, resulting in yield loss from reduced stalk length (33). In West Africa, the ectoparasitic nematode community generally is dominated by $H$. dihystera; whereas, in South Africa, the latter is usually a smaller component of the community, in which more harmful nematodes such as $X$. elongatum are dominant (33). In parallel, nematode damage to sugarcane on sandy soils tends to be more severe (and yield

Corresponding author: Y. Moënne-Loccoz

E-mail address: moenne@biomserv.univ-lyon1.fr

Publication no. P-2003-0827-01R

(C) 2003 The American Phytopathological Society lower) in South Africa compared with West Africa, and it is believed that this damage level is linked to the relative importance of $H$. dihystera (32). However, other factors also may determine the outcome of nematode attacks on the crop, such as differences in soil properties (other than texture), climate, sugarcane cultivar, or farming practices.

The composition of the soil community of phytoparasitic nematodes has been surveyed for years in sugarcane areas in South Africa, especially in Kwazulu Natal. As elsewhere in South Africa, most records for Kwazulu Natal confirmed that $H$. dihystera was not very dominant in sandy soils, and the latter were conducive to ectoparasitic nematode damage. Unexpectedly, in a minority of sandy soil fields, $H$. dihystera was found at higher levels, a situation reminiscent of that observed in West Africa. In parallel, yields were higher and the crop needed less frequent replanting. Those soils suppressive to ectoparasitic nematode damage were cropped with the same cultivar and the same farming practices as the conducive soils; therefore, this situation provided a unique opportunity to compare, within the same geographic area, sandy fields exhibiting contrasted communities of phytoparasitic nematodes.

In this investigation, two sugarcane monoculture sites (one suppressive and the other conducive to damage caused by ectoparasitic nematodes) with soils of similar sandy texture were selected in Kwazulu Natal based on previous nematode records. First, the composition of the parasitic nematode community of both field sites was determined. Second, soil was analyzed to assess whether there was a relationship between soil characteristics and parasitic nematode community. Third, a greenhouse pot comparison of both soils assessed whether climatic differences between the sites could be meaningful in terms of parasitic nematode community composition and plant growth. Fourth, the bacterial community at both sites was compared, because it is well established that soil bacteria can have a significant effect on populations of phytoparasitic nematodes $(4,6,7,30)$. To this end, counts of resident bacteria 
were carried out and the bacterial community was characterized by automated ribosomal intergenic spacer analysis (RISA).

\section{MATERIALS AND METHODS}

Field sites. The two field sites (La Mercy, 29 $37^{\prime}$ south and $31^{\circ} 05^{\prime}$ east; and Compensation, $29^{\circ} 31^{\prime}$ south and $31^{\circ} 09^{\prime}$ east) were chosen based on different population levels of $H$. dihystera. These sites are located $25 \mathrm{~km}$ apart in the coastal area of Kwazulu Natal (southeastern part of South Africa). H. dihystera predominates at Compensation (suppressive soil; cane yield of 50 to $70 \mathrm{t} / \mathrm{ha}$ ) but not at La Mercy (conducive soil; cane yield 30 to $40 \mathrm{t} / \mathrm{ha}$ ), which was confirmed in this study (described below). The two fields have been under continuous sugarcane cropping for more than a century and, in recent years, cv. N12 was used at both sites. The crop corresponded to the eighth (Compensation) and ninth (La Mercy) regrowth of ratoon cane at the time of the study. The soil at both locations developed from quaternary sand deposits and belongs to the Coastal Sand System (South Africa Soil Classification System), which corresponds to Dystric Regosols in the FAO system (syn. Entisols in the United States Department of Agriculture Soil Taxonomy).

A 30-m transect parallel to sugarcane rows was randomly chosen at each site. Six adjacent $25-\mathrm{m}^{2}$ plots were defined along each transect, yielding plots LM1 to LM6 (La Mercy) and C1 to C6 (Compensation). Plots were at least $10 \mathrm{~m}$ away from the border of the field. The six plots per site were considered as replicates.

Sampling of rhizosphere soil. A first sampling was carried out in November 1999 (i.e., 3 months after the August harvest), and plant shoots were $\approx 50$ to $60 \mathrm{~cm}$ high. Soil samples were taken from the 20-cm-deep topsoil, below one plant chosen randomly within each plot. The sandy soil adhered poorly to the roots and was recovered easily by shaking the root system. The samples were used for analysis of physical and chemical soil properties, to study nematode populations, and to set up a greenhouse pot experiment (see below). A second sampling was carried out in April 2000 (a majority of shoots were $\approx 150 \mathrm{~cm}$ high) to assay nematode and bacterial populations. At each sampling time, one sample was taken from each of the 12 plots and it was subsequently subdivided for the different analyses. Soil was highly colonized by roots, even at La Mercy, and the whole soil horizon could be considered as rhizosphere soil.

Analysis of nematode populations. Nematodes were extracted from $200 \mathrm{~cm}^{3}$ of rhizosphere soil by elutriation (29), examined under the microscope for taxonomic identification, and counted. One sample was studied per plot at each of the two sampling times.

Bacterial enumerations. Soil samples ( $1 \mathrm{~g}$ each) were added to $9 \mathrm{ml}$ of $0.9 \% \mathrm{NaCl}$ solution and bacterial cells extracted by shak- ing (150 rpm, $15 \mathrm{~min}$ ) followed by vortexing ( $5 \mathrm{~min})$. Dilution series were prepared in $0.9 \% \mathrm{NaCl}$ solution. The total number of bacterial cells was determined (one sample used per plot) by direct epifluorescence microscopic observation (on $0.2-\mu \mathrm{m}$ polycarbonate filters; Nucleopore, Cambridge, MA) of rhizosphere samples after the addition of acridine orange (26). For each sample, a total of 20 microscope fields were studied.

Culturable bacteria were enumerated using three other 1-g soil samples per plot (36 samples in total), as follows. The total number of culturable aerobic bacteria was obtained on $10 \%$ tryptic soy agar (BioMérieux SA, Marcy l'Etoile, France) containing the antifungal compound amphotericin B $(1.25 \mu \mathrm{g} / \mathrm{ml}$; ICN, Orsay, France). The culturable fluorescent pseudomonads were counted on S1 agar (11). The number of culturable Burkholderia-like (i.e., putative Burkholderia) bacteria was estimated using the semiselective medium PCAT (19). Colonies were counted after an 8-day incubation of plates at $28^{\circ} \mathrm{C}$ and means were taken for each plot.

Molecular fingerprinting of the bacterial community by automated RISA. The RISA procedure described below was implemented for two samples per plot ( 24 samples in total). First, DNA was obtained from 3-g rhizosphere soil samples by cell lysis in situ $(23,24)$. Briefly, each sample was subjected successively to mechanical grinding (in liquid nitrogen), enzymatic lysis (lysozyme and proteinase $\mathrm{K}$ ), and chemical lysis (hexadecyltrimethylammonium bromide). Sequential DNA purification was performed using, successively, chloroform and isoamylic alcohol extraction, isopropanol precipitation, and chromatography with a S400-HR acrylamide column (Amersham Pharmacia Biotech, Orsay, France) and an ion exchange column (DNeasy Plant Mini Kit; Qiagen S.A., Courtaboeuf, France), according to Ranjard et al. (24). DNA quantification was done by comparison with calf thymus DNA standards in $0.8 \%$ agarose electrophoretic gel containing ethidium bromide, using image analysis software (Bio-Rad, Ivry-sur-Seine, France).

Second, the $r r s-r r l$ intergenic spacer region was amplified by polymerase chain reaction (PCR) using primers S-D-Bact-1522-bS-20 (small eubacterial ribosomic subunit; 5'-TGCGGCTGGATCCCCCTCCTT-3'), which was labeled at its $5^{\prime}$ end with the fluorochrome 6-carboxyhexafluorescein (HEX; Perkin-Elmer, Courtaboeuf, France), and L-D-Bact-132-a-A-18 (large eubacterial ribosomic subunit; 5'-CCGGGTTTCCCCATTCGG-3') (17). In addition to the intergenic spacer, the amplicons also contained $20 \mathrm{bp}$ corresponding to primer S-D-Bact-1522-b-S-20 and $\approx 130$ bp from $\mathrm{rrl}$. PCR amplification was done as described by Ranjard et al. (25).

Third, banding patterns were generated by denaturating polyacrylamide gel (6\%) electrophoresis using an ABI 373 DNA sequencer $(12 \mathrm{~h}, 1,500 \mathrm{~V})$ with laser detection. Samples consisted of 2 to $3 \mu \mathrm{l}$ of amplicon solution previously denaturated for $5 \mathrm{~min}$ at

TABLE 1. Populations of parasitic nematodes at the November 1999 and April 2000 samplings in rhizosphere soil (log number of nematodes/dm ${ }^{3}$ of soil) at La Mercy and Compensation (mean \pm standard deviation; $n=6)^{\mathrm{a}}$

\begin{tabular}{|c|c|c|c|c|}
\hline \multirow[b]{2}{*}{ Nematodes $^{\mathrm{b}}$} & \multicolumn{2}{|c|}{ November sampling ${ }^{\mathrm{c}}$} & \multicolumn{2}{|c|}{ April sampling ${ }^{\mathrm{c}}$} \\
\hline & La Mercy & Compensation & La Mercy & Compensation \\
\hline \multicolumn{5}{|l|}{ Endoparasites } \\
\hline Pratylenchus zeae & $3.00 \pm 0.21(69 \%)$ & $2.50 \pm 0.63(92 \%)$ & $3.17 \pm 0.30(65 \%)$ & $2.00 \pm 0.69(100 \%) \#$ \\
\hline Total & $3.17 \pm 0.22[28 \%]$ & $2.55 \pm 0.58[6 \%] \# *$ & $3.36 \pm 0.23[53 \%]$ & $2.00 \pm 0.69[1 \%] \# *$ \\
\hline \multicolumn{5}{|l|}{ Ectoparasites } \\
\hline Helicotylenchus dihystera & $3.31 \pm 0.24(52 \%)$ & $3.95 \pm 0.29(89 \%) \# *$ & $3.04 \pm 0.24(54 \%)$ & $3.79 \pm 0.20(79 \%) \#$ \\
\hline Total parasites & $3.76 \pm 0.12$ & $4.13 \pm 0.29$ & $3.63 \pm 0.10$ & $3.90 \pm 0.28 \#$ \\
\hline
\end{tabular}

$\bar{a}$ At each sampling, significant differences $(P<0.05)$ between sites are indicated by * (percentages) or \# (numbers). Free-living nematodes amounted to $2.13 \pm$ 1.18 (La Mercy) and $1.83 \pm 1.16 \log / \mathrm{dm}^{3}$ of soil (Compensation) in November and 3.78 \pm 0.23 (La Mercy) and $3.58 \pm 0.28 \log / \mathrm{dm}^{3}$ of soil (Compensation) in April.

${ }^{\mathrm{b}} \mathrm{H}$. dihystera, X. elongatum, and P. minor represented at least $95 \%$ of all ectoparasites.

$\mathrm{c}$ Percentage of the total number of endoparasitic or ectoparasitic nematodes is indicated in parentheses and percentage of the total number of parasitic nematodes is indicated in brackets. 
$95^{\circ} \mathrm{C}, 0.5 \mu \mathrm{l}$ of red fluorescent size standard (GeneScan 1,000-bp ROX; Perkin-Elmer), $0.75 \mu \mathrm{l}$ of blue marker, and $1.25 \mu \mathrm{l}$ of deionized formamide (to maintain denaturing conditions). The data were analyzed by the GeneScan 3.1 software program (PerkinElmer). The software converted fluorescence data into electrophoregrams; the peaks represented fragments of different sizes and the heights of the peaks were the relative proportion of the fragments in the total product. Lengths (in base pairs) were calculated by using the size standards in conjunction with the nosmoothing option and the Local Southern method in GeneScan. The relative peak intensities (i.e., height or area) within a profile were calculated by dividing the intensity of an individual peak by the total profile intensity (sum of the intensities of all peaks).

Greenhouse pot experiment. To assess whether the diseasesuppressive status of the Compensation site was linked to particular microclimatic conditions, ectonematode community and plant growth conditions were monitored for Compensation and $\mathrm{La}$ Mercy soil incubated under the same climatic conditions (greenhouse). The greenhouse ( 25 to $26^{\circ} \mathrm{C}, 80$ to $85 \%$ relative humidity) was located in Mount Edgecombe, Kwazulu Natal. Sieved (10-mm grid) soil was sampled in November from both sites and used to fill the pots. One $25-\mathrm{dm}^{3}$ pot ( $\approx 28 \mathrm{~kg}$ of dry soil in each) was prepared from each of the 12 plots, and pot location in the greenhouse followed a randomized design. Two germinated internodes (with a stalk $\approx 10 \mathrm{~cm}$ high) were planted in each pot and, at 5 months (April), destructive sampling was carried out to assess nematode populations (as described previously) and development of plant cane.

Statistical analysis. Each plot (field) or pot (greenhouse) was considered as a replication $(n=6)$. Population level data (nematodes and bacteria) and percentages were $\log (x+1)$ and arcsine transformed, respectively, before calculating means and performing statistical analyses. Data are shown \pm standard deviation. Analysis of variance (ANOVA) was carried out using Statview-SE
(Abacus Concepts Inc., Berkeley, CA) at the $P<0.05$ level. Principal component analysis (PCA) was based on correlation levels (for nematode or soil composition data) or covariance matrix (for automated RISA data; i.e., presence or absence of bands and their intensity) and was done using ADE-4 software (37). PCA is an ordination method (13) that analyzes the relative position of $n$ individuals (here, the 12 field plots), each characterized by $p$ variables (here, nematode species, soil characteristics, or RISA bands). Such data are represented by a $p$-dimensional space. Making linear transformations of the original axes, PCA expresses a decreasing part of the variance along a series of new, composite axes (13). Generally, only the two first axes (PC1 and PC2) are analyzed. The analysis provides ordination of the $n$ individuals and the $p$ variables. Here, it was used to compare field plots between the two sites, or to illustrate the correlation between variables (nematode species or soil characteristics). Prior to PCA, automated RISA data obtained from the GeneScan software were converted into a table summarizing band presence (i.e., peak) and intensity (i.e., height or area of peak) using the PrepRISA software. PrepRISA allowed us to choose the number of peaks (i.e., all detected populations versus most dominant populations), the profile resolution (between 1 and $10 \mathrm{bp}$ ), and the method of evaluating peak intensity (height or area). In this study, results were obtained with a 1-bp resolution considering all peaks over the entire gel length and using the height to determine peak intensity.

\section{RESULTS}

Comparison of nematode populations. When considering data obtained at the two sampling times, the total number of parasitic nematodes in the rhizosphere was $3.7 \mathrm{log} / \mathrm{dm}^{3}$ (at La Mercy) and $4.0 \mathrm{log} / \mathrm{dm}^{3}$ (at Compensation) (Table 1). The difference between the two sites was statistically significant in April 2000 but not in November 1999. A similar situation was found for the
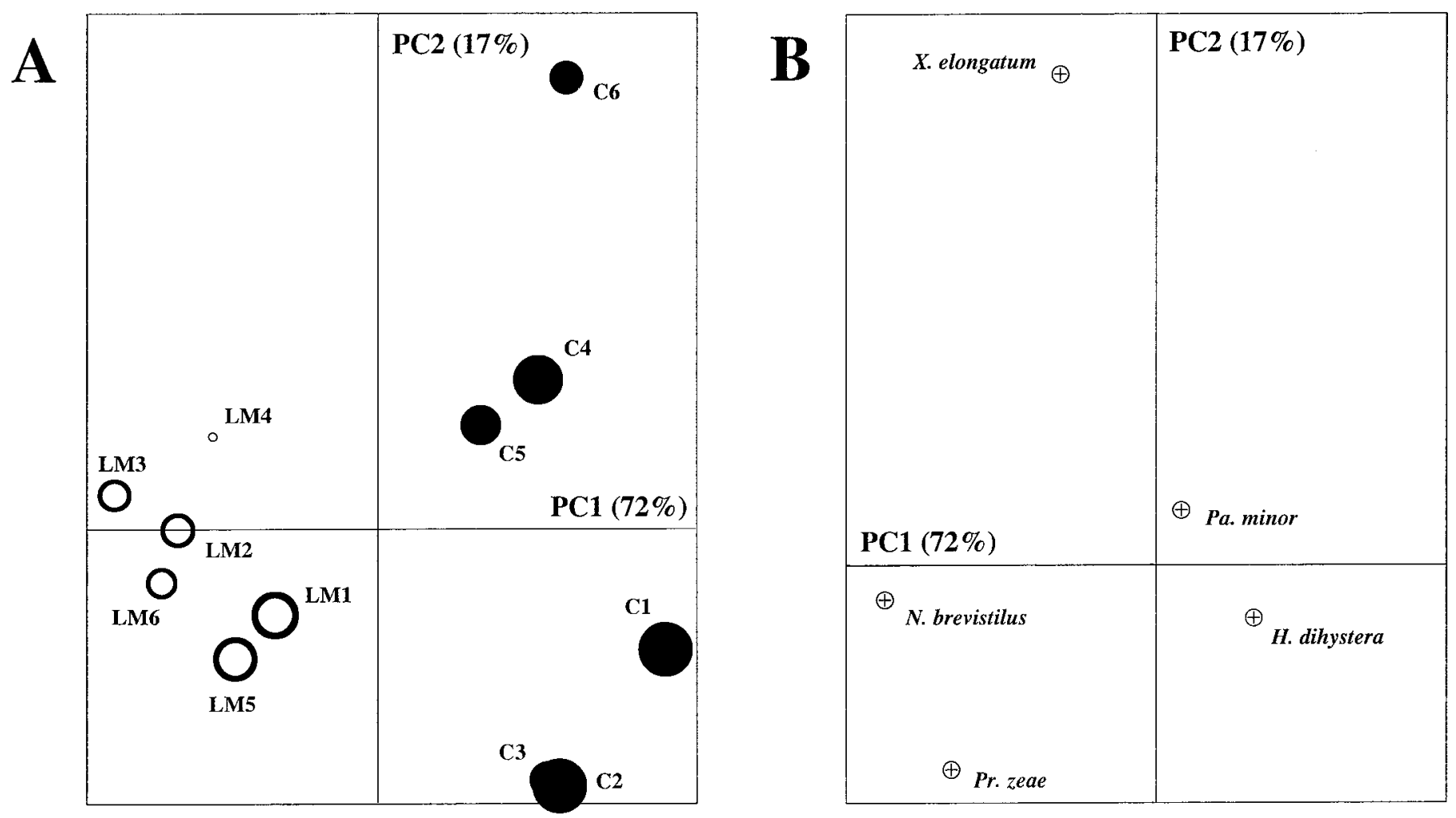

Fig. 1. Principal component analysis (PCA) of nematode data obtained in April 2000 for comparison A, of the six plots at La Mercy (i.e., LM1 to LM6) and the six plots at Compensation (i.e., C1 to C6) and B, of nematode species. A, Diameter of each symbol is proportional to the prevalence of Helicotylenchus dihystera among the ectoparasitic nematode community (from 15 to 94\%). Analysis of PCA results needs to be done based on location of data along the first axis (which explains as much as $72 \%$ of all data variation), then along the second axis (which explains only $17 \%$ of data variation). PCA results were similar when the data from November 1999 were used (data not shown). 
number of ectoparasitic nematodes (3.5 and $3.9 \mathrm{log} / \mathrm{dm}^{3}$ at $\mathrm{La}$ Mercy and Compensation, respectively), which differed statistically in April but not in November. Among the ectoparasites, only the number of $H$. dihystera differed significantly between the two

TABLE 2. Physical and chemical soil characteristics of La Mercy and Compensation (mean \pm standard deviation; $n=6)^{\mathrm{a}}$

\begin{tabular}{|c|c|c|}
\hline Characteristics $^{\mathrm{b}}$ & La Mercy & Compensation \\
\hline Clay $\%$ & $7.6 \pm 1.6$ & $6.9 \pm 0.5$ \\
\hline Silt $\%$ & $8.8 \pm 1.1$ & $8.4 \pm 0.8$ \\
\hline Sand $\%$ & $83.7 \pm 2.7$ & $84.7 \pm 0.9$ \\
\hline Texture & Silty sand & Silty sand \\
\hline $\mathrm{pH}\left(\mathrm{H}_{2} \mathrm{O}\right)$ & $4.8 \pm 0.1$ & $4.3 \pm 0.2 *$ \\
\hline Organic matter \% & $1.42 \pm 0.06$ & $2.37 \pm 0.29 *$ \\
\hline $\mathrm{N}$ total $\%$ & $0.07 \pm 0.01$ & $0.12 \pm 0.03 *$ \\
\hline $\mathrm{C} / \mathrm{N}$ ratio & $10.7 \pm 1.4$ & $11.3 \pm 1.9$ \\
\hline P (Truog) ppm & $24 \pm 5$ & $18 \pm 4^{*}$ \\
\hline CEC meq $\%$ & $2.3 \pm 0.3$ & $2.4 \pm 0.2$ \\
\hline $\mathrm{Ca}\left(\left[\mathrm{NH}_{4}\right]_{2} \mathrm{CO}_{3}\right) \mathrm{meq} \%$ & $0.5 \pm 0.2$ & $0.3 \pm 0.1 *$ \\
\hline $\mathrm{Mg}\left(\left[\mathrm{NH}_{4}\right]_{2} \mathrm{CO}_{3}\right) \mathrm{meq} \%$ & $0.22 \pm 0.07$ & $0.09 \pm 0.02 *$ \\
\hline $\mathrm{K}\left(\left[\mathrm{NH}_{4}\right]_{2} \mathrm{CO}_{3}\right) \mathrm{meq} \%$ & $0.30 \pm 0.10$ & $0.18 \pm 0.09 *$ \\
\hline $\mathrm{Na}\left(\left[\mathrm{NH}_{4}\right]_{2} \mathrm{CO}_{3}\right) \mathrm{meq} \%$ & $0.20 \pm 0.10$ & $0.17 \pm 0.03$ \\
\hline $\mathrm{Al}\left(\mathrm{NH}_{4} \mathrm{Cl}\right) \mathrm{ppm}$ & $32 \pm 6$ & $60 \pm 8^{*}$ \\
\hline $\mathrm{Zn}\left(\mathrm{EDTA}\left[\mathrm{NH}_{4}\right]_{2} \mathrm{CO}_{3}\right) \mathrm{ppm}$ & $1.7 \pm 0.3$ & $1.4 \pm 0.7$ \\
\hline $\mathrm{Mn}\left(\mathrm{EDTA}\left[\mathrm{NH}_{4}\right]_{2} \mathrm{CO}_{3}\right) \mathrm{ppm}$ & $33.2 \pm 26.8$ & $2.8 \pm 0.7^{*}$ \\
\hline $\mathrm{Fe}\left(\mathrm{EDTA}\left[\mathrm{NH}_{4}\right]_{2} \mathrm{CO}_{3}\right) \mathrm{ppm}$ & $231 \pm 4$ & $247 \pm 2^{*}$ \\
\hline
\end{tabular}

a Significant differences $(P<0.05)$ between sites are indicated by an asterisk.

${ }^{\mathrm{b}} \mathrm{CEC}=$ cation exchange capacity.

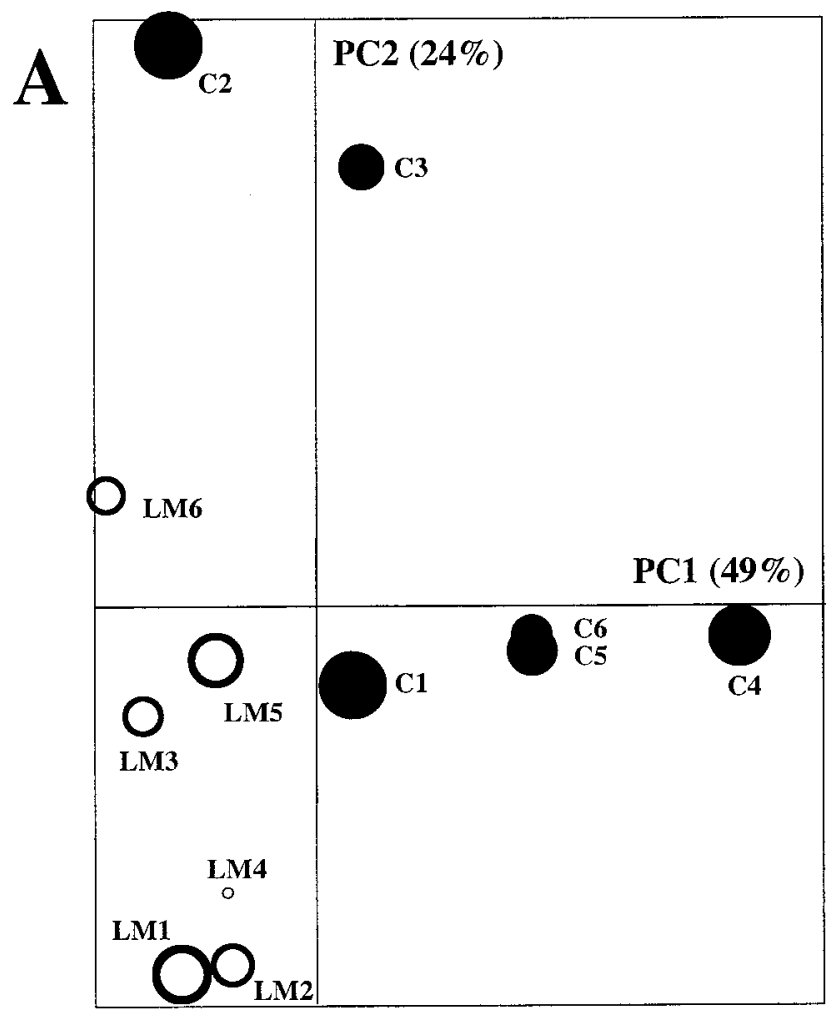

sites in November and in April, its population being higher at Compensation by $0.7 \mathrm{log}$ units. H. dihystera represented 52 to $54 \%$ and 79 to $89 \%$ of all ectoparasitic nematodes at La Mercy and Compensation, respectively, and the percentage difference between the two was statistically significant in November but not in April.

Endoparasitic nematodes also were found, but at low population levels (Table 1). At both samplings, endoparasitic nematodes were more numerous in the rhizosphere at La Mercy than Compensation, and only at La Mercy accounted for a significant percentage of all parasitic nematodes (Table 1). In April, the endoparasitic nematodes also were studied in soil-free roots after mist extraction of 10- to 15-g root samples. Mainly Pratylenchus zeae was found (data not shown), at population levels that were small but statistically higher at La Mercy $(2.16 \pm 0.27 \mathrm{log} / \mathrm{g}$ of root) compared with Compensation $(0.96 \pm 0.89 \mathrm{log} / \mathrm{g}$ of root).

The distribution of nematodes within a field can be heterogeneous, even under monocot monoculture (43); therefore, PCA was carried out to compare the plots from both sites. At each of the two samplings, PCA detected differences in the plots from $\mathrm{La}$ Mercy and Compensation (Fig. 1A; April data), based on numbers of parasitic nematodes in the rhizosphere. Compensation plots were grouped more loosely than La Mercy plots (Fig. 1B; April data).

Comparison of soil properties. Both soils were sandy soils and displayed similar cation exchange capacity (CEC) and $\mathrm{C} / \mathrm{N}$ ratio (Table 2). However, La Mercy differed significantly (ANOVA) from Compensation based on several characteristics,

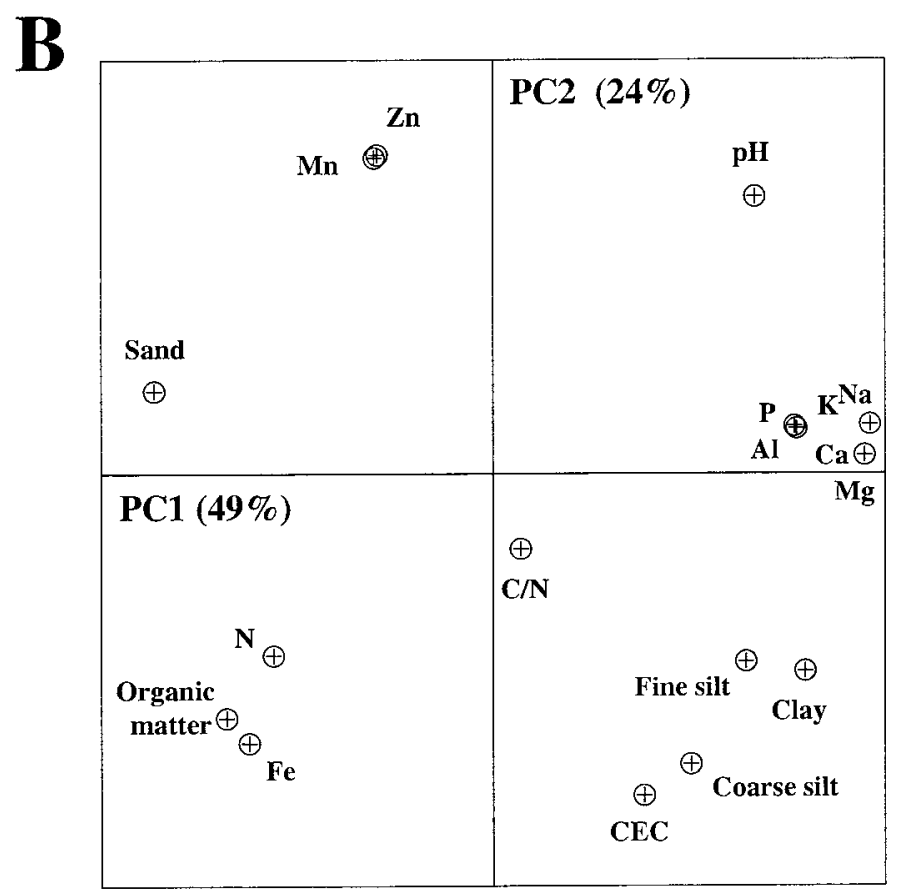

Fig. 2. Principal component analysis of soil composition data for comparison of A, the six plots at La Mercy (i.e., LM1 to LM6) and the six plots at Compensation (i.e., C1 to C6) and B, of physical and chemical soil characteristics. A, Diameter of each symbol is proportional to the prevalence of Helicotylenchus dihystera among the ectoparasitic nematode community (from 15 to $94 \%$ ).

TABLE 3. Significant correlations (Pearson correlation coefficient; $P<0.05$ ) between soil characteristics (physical and chemical parameters) and nematode data obtained in April 2000

\begin{tabular}{|c|c|c|c|c|c|c|c|c|}
\hline Nematode data & $\begin{array}{c}\% \text { Organic } \\
\text { matter }\end{array}$ & $\mathrm{pH}$ & $\mathrm{N}$ total $\%$ & Ca meq\% & $\mathrm{Mg}$ meq\% & Mn ppm & Fe ppm & $\mathrm{Al} \mathrm{ppm}$ \\
\hline Log number Pratylenchus zeae $/ \mathrm{dm}^{3}$ of soil & -0.82 & +0.74 & -0.77 & $\ldots$ & $\ldots$ & $\ldots$ & -0.76 & $\ldots$ \\
\hline Log number Helicotylenchus dihystera/ $\mathrm{dm}^{3}$ of soil & +0.89 & -0.93 & +0.71 & -0.74 & -0.82 & $\ldots$ & +0.90 & +0.83 \\
\hline H. dihystera $(\%)$ in ectoparasites & +0.71 & -0.79 & $\ldots$ & -0.75 & $\ldots$ & -0.76 & $\ldots$ & $\ldots$ \\
\hline
\end{tabular}


such as lower organic matter (1.42 versus $2.37 \%), \mathrm{N}, \mathrm{Al}$, and $\mathrm{Fe}$; and higher $\mathrm{P}, \mathrm{Ca}, \mathrm{Mg}, \mathrm{K}, \mathrm{Mn}$, and $\mathrm{pH}$ (4.8 versus 4.3). PCA indicated that the six plots at La Mercy could be distinguished from those at Compensation (Fig. 2A). Axis PC1 (49\% of the variance) was associated with $\mathrm{Ca}, \mathrm{Mg}, \mathrm{K}, \mathrm{Na}, \mathrm{Al}, \mathrm{P}$, sand, $\mathrm{Fe}$, organic matter and $\mathrm{N}$; and axis PC2 (24\% of the variance) with CEC, silt, Mn, and Zn (Fig. 2B). PCA (along with variation coefficients of individual parameters; data not shown) also showed that interplot variability was higher at Compensation.

TABLE 4. Helicotylenchus dihystera population and root biomass at the end of the 5-month-old greenhouse pot experiment carried out with soil from La Mercy and Compensation $(n=6)^{\mathrm{a}}$

\begin{tabular}{lcc}
\hline Nematode data and plant data & La Mercy & Compensation \\
\hline Log number $H$. dihystera $/ \mathrm{dm}^{3}$ of soil & $3.31 \pm 0.27$ & $3.95 \pm 0.20^{*}$ \\
H. dihystera $(\%)$ in ectoparasites & $57 \pm 19$ & $89 \pm 7^{*}$ \\
Root biomass (dry root, g/plant) & $25 \pm 20$ & $38 \pm 19$ \\
\hline
\end{tabular}

a Mean \pm standard deviation. Significant differences $(P<0.05)$ between sites are indicated by an asterisk.

TABLE 5. Bacterial population levels at the April 2000 sampling in rhizosphere soil at La Mercy and Compensation (mean \pm standard deviation; $n=6)^{\mathrm{a}}$

\begin{tabular}{lrc}
\hline Bacterial numbers $(\log$ cells/g of soil) & La Mercy & Compensation \\
\hline Total bacterial cells & $10.5 \pm 0.8$ & $10.2 \pm 0.4$ \\
Total culturable aerobic bacteria & $7.6 \pm 0.5$ & $7.8 \pm 0.3$ \\
Culturable fluorescent pseudomonads & $3.4 \pm 0.7$ & $2.5 \pm 0.3 *$ \\
Culturable Burkholderia-like bacteria & $6.9 \pm 0.4$ & $7.0 \pm 0.3$ \\
\hline
\end{tabular}

a Significant differences $(P<0.05)$ between sites are indicated by an asterisk.
Several statistically significant correlations were found between soil parameters (particularly organic matter content and $\mathrm{pH}$ ) and nematode parameters obtained from the rhizosphere in April 2000. Organic matter content was correlated negatively with the population level of Pratylenchus zeae and positively with the population level of $H$. dihystera and its prevalence among ectoparasites; whereas, for $\mathrm{pH}$, the correlation was positive with the population level of Pratylenchus zeae and negative with the population level of $H$. dihystera and its prevalence among ectoparasites (Table 3).

Role of microclimatic differences between sites. The soils from La Mercy and Compensation were studied side by side in a greenhouse pot experiment. Five months after planting, the nematode community in the mesocosms was comparable to the community present in situ (data not shown). In particular, both the population level of $H$. dihystera and its prevalence among ectoparasites were higher in the Compensation treatment than in the La Mercy treatment (Table 4). At 5 months, plant cane was $\approx 1 \mathrm{~m}$ high and plant biomass was similar in both treatments. Root biomass was $25 \mathrm{~g} /$ plant in La Mercy soil versus $38 \mathrm{~g} / \mathrm{plant}$ in Compensation soil (Table 4), but data fluctuation was high and the treatments did not differ significantly at $P<0.05$.

Comparison of bacterial population levels in the field. No difference was found between field sites regarding the total number of bacterial cells present in the rhizosphere or the total number of culturable aerobic bacteria on $10 \%$ tryptic soy agar (Table 5). At both sites, these culturable aerobic bacteria accounted for $\approx 0.15 \%$ of all bacterial cells. Two particular groups of culturable bacterial species were quantified and results indicated that the number of culturable fluorescent pseudomonads was $\approx 10$ times lower at Compensation compared with La Mercy (Table 5). Significant correlations were found between the number of culturable
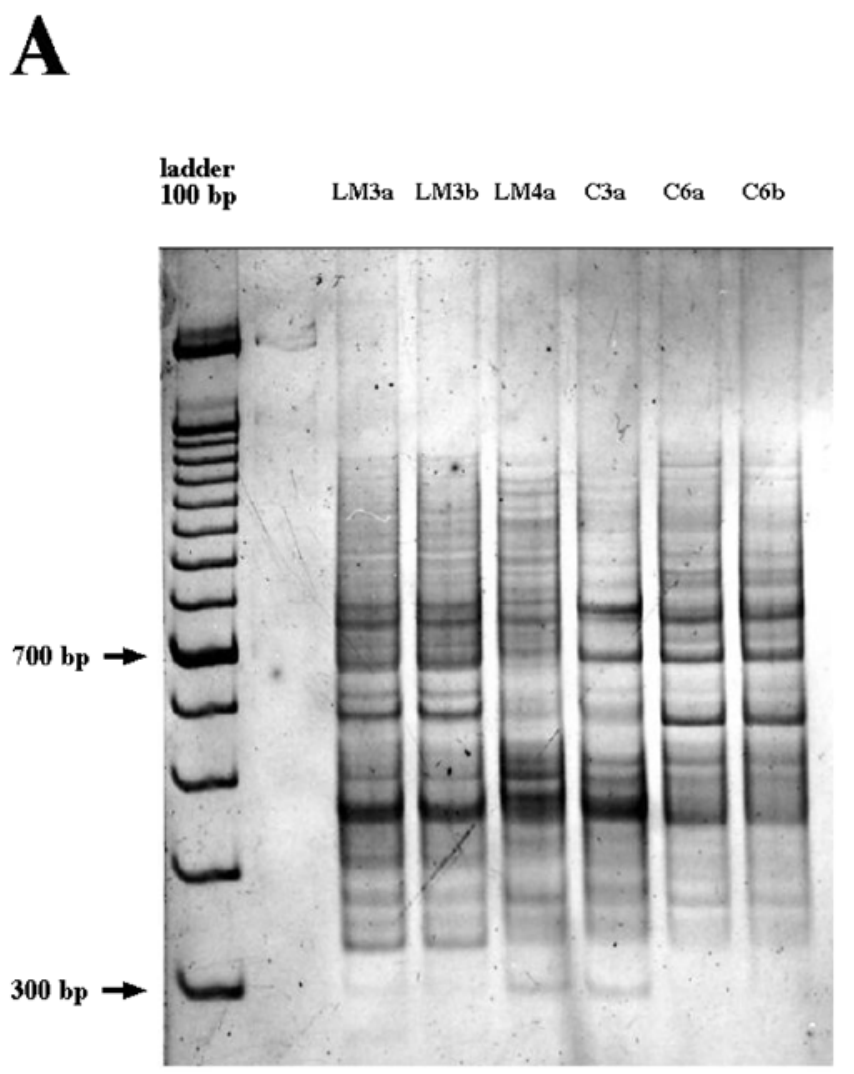

B
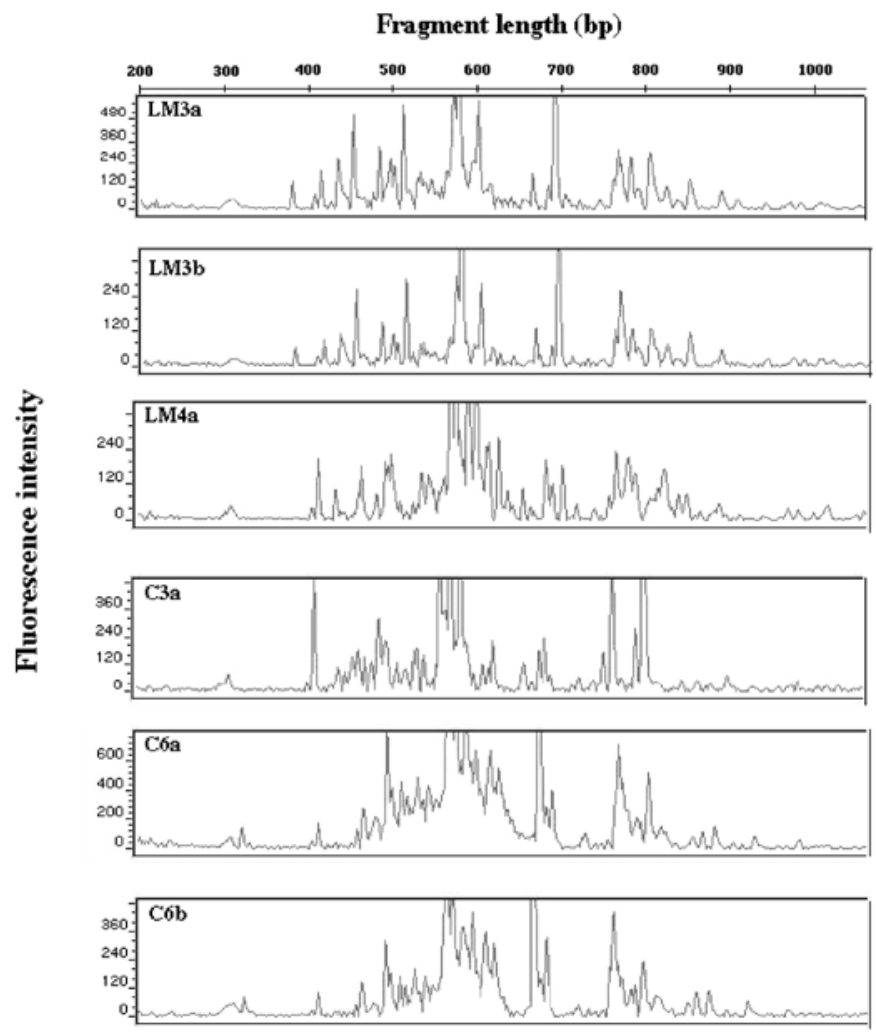

Fig. 3. Ribosomal intergenic spacer analysis (RISA) of the bacterial community. A, Manual RISA profiles (obtained as described in Ranjard et al. [23]) resolved on 5\% nondenaturing polyacrylamide gel. B, Automated RISA electrophoregrams obtained from rhizosphere samples of La Mercy (repetitions a and b for plot LM3 and one repetition for plot LM4) and Compensation (repetitions a and b for plot C6 and one repetition for plot C3). 
fluorescent Pseudomonas spp. (but not the total number of bacterial cells or of culturable aerobic bacteria) and the proportion of $H$. dihystera $(r=-0.81 ; P=0.0072)$ and Paratrichodorus minor $(r=0.92 ; P=0.0001)$ among the ectoparasites in November (but not in April). Counts of Burkholderia-like bacteria were the same at both sites (Table 5).

RISA fingerprints of the bacterial community in the field. Manual RISA profiles (performed as described by Ranjard et al. [23]) and automated RISA electrophoregrams were obtained for each plot (Fig. 3). RISA gave reproducible results, as indicated by the comparison of manual or automated RISA fingerprints obtained when the whole procedure was repeated (Figs. 3 and 4). Different banding patterns were evidenced when comparing the two sites, but also different plots within a site. PCA was carried out on the automated RISA data to analyze in more details the 12

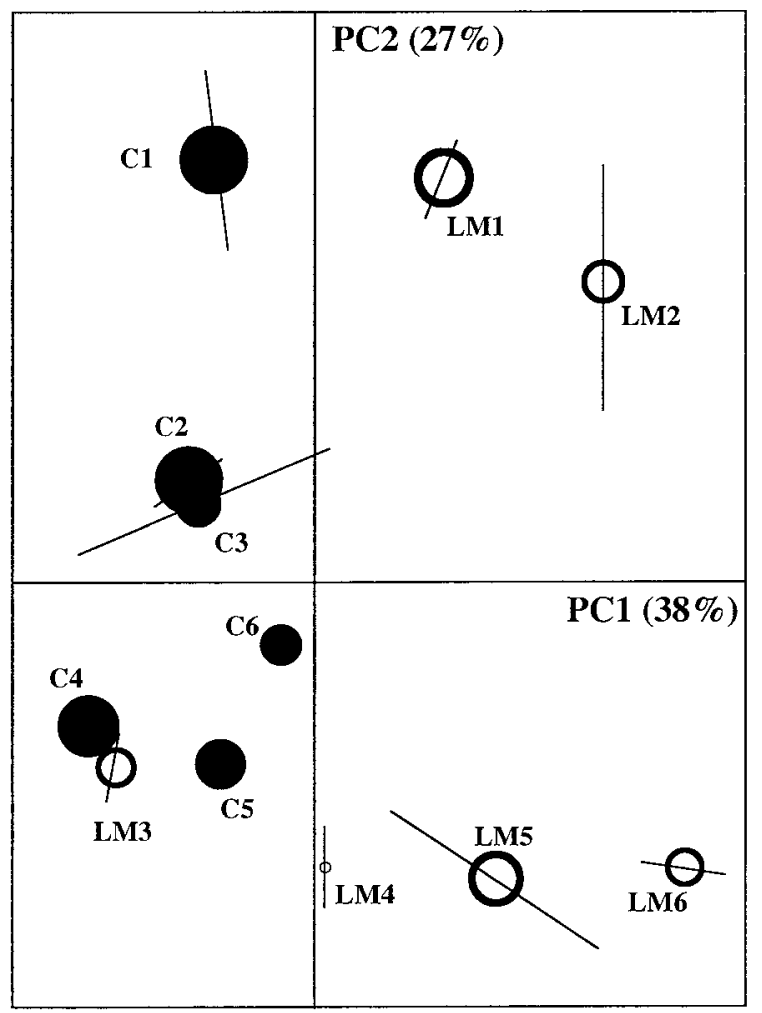

Fig. 4. Principal component analysis (PCA) of automated ribosomal intergenic spacer analysis (RISA) data for comparison of the six plots at $\mathrm{La}$ Mercy (i.e., LM1 to LM6) and the six plots at Compensation (i.e., C1 to C6). For each plot, the two replications of the RISA procedure were used for PCA (except for C5, where only one replication was available) and a line was used to link both points (the symbol is placed in the middle). The diameter of each symbol is proportional to the prevalence of Helicotylenchus dihystera among the ectoparasitic nematode community (from 15 to $94 \%$ ). plots studied. PCA partially distinguished the plots at Compensation from those at la Mercy based on the first two axes, which explained 38 and $27 \%$ of the total variation (Fig. 4). It can be noted that both sites exhibited variability, especially La Mercy. Whereas Compensation plots grouped together along the first axis, La Mercy plots were spread out along both the first (with plot LM3 located among Compensation plots) and the second (with plots LM1 and LM2 located opposite to the other La Mercy plots) axis. Field site heterogeneity in terms of automated RISA data prevented us from identifying bands that were site-specific or more intense in the fingerprints of all plots from one site. This is shown in Table 6, which lists the major bands allowing PCA ordination on the first two axes. No significant correlations were found between automated RISA parameters for the first two axes and (i) soil composition parameters (Table 3 ) or (ii) the percentage of $H$. dihystera among ectoparasites.

\section{DISCUSSION}

Certain field sites are known to be suppressive to particular soilborne diseases, meaning that disease severity is kept to a minimum because the pathogen does not manage to reach sufficient population levels for infection or express its virulence toward a susceptible host $(5,12)$. In some cases, suppressiveness is a natural property of the soil and is conserved through crop rotations; for instance, in the morainic soils from Morens (near Fribourg, Switzerland) naturally suppressive to disease caused by Thievaliopsis basicola to tobacco $(21,36)$. In others, disease suppressiveness develops as a result of crop monoculture, as for take-all decline of wheat $(5,38)$.

Often, suppressiveness concerns soilborne fungal pathogens, and a smaller number of cases are documented for parasitic nematodes $(10,14,35,42,44)$, especially for ectoparasitic nematodes (15). In this investigation, it appears that Compensation would fit the conceptual definition of a suppressive soil. First, ectoparasitic nematodes were present in the rhizosphere at rather high levels (similar or higher than those in La Mercy conducive soil; Table 1), which a priori were sufficient for significant damage $(32,34)$. Second, nematode damage was of minor significance (and less than at other sugarcane sites in the area; e.g., at La Mercy, which required more frequent replanting) despite the use of a susceptible cultivar. Third, yield was higher compared with yields on most other agronomically similar sandy soils in Kwazulu Natal (32). Endoparasitic nematodes also were found, especially at La Mercy, but nematode damage to the crop was caused mainly by ectoparasites, as already observed elsewhere in South African sandy soils (32). Indeed, population levels of endoparasitic nematodes (such as Pratylenchus zeae) in the rhizosphere (Table 1) and in the roots (data not shown) were too low at both sites to cause significant damage (34). The large predominance of $H$. dihystera at Compensation, which is unusual in sandy soils in South Africa, seems to be a stable feature of the site as it was first identified

TABLE 6. Automated ribosomal intergenic spacer analysis bands involved in principal component analysis ordination of the bacterial community on the two first axes

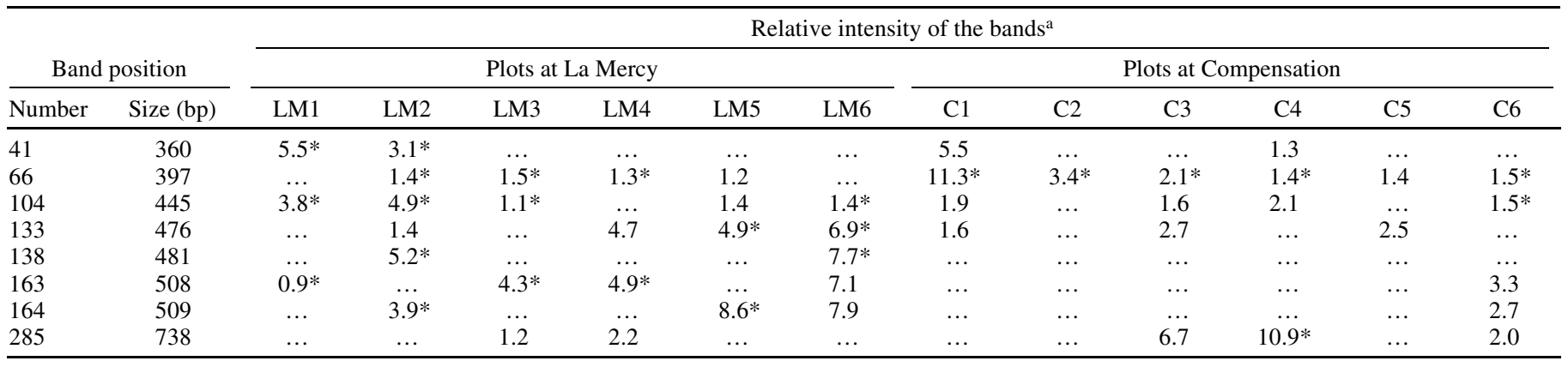

a An asterisk is used to indicate discriminating bands found twice (i.e., with both DNA extractions), in which case data indicates the mean band intensity. 
years ago, and here confirmation was obtained at both field samplings (Table 1).

Soil properties often are major factors shaping the assembly and structure of the nematode community $(2,43)$. Here, the soils at La Mercy and Compensation displayed the same texture, and in addition they did not differ based on important features such as C:N ratio and CEC (Table 2). Significant differences were found when looking at other soil properties (e.g., N content); however, most importantly, such differences could not explain in agronomic terms the large difference in yield between the two sites (28). On one hand, the fertility status may appear somewhat higher at Compensation based on higher soil organic matter (probably resulting from differences in crop productivity and in the amount of crop residues) and $\mathrm{N}$ contents; but, on the other hand, La Mercy displayed a less acidic $\mathrm{pH}$, a less unsaturated $\mathrm{CEC}$, and a higher $\mathrm{P}$ content.

Among the soil factors that differed at Compensation and $\mathrm{La}$ Mercy, $\mathrm{pH}$ and contents in organic matter, $\mathrm{Al}, \mathrm{Fe}$, and $\mathrm{Mn}$ were identified previously as playing a part in the suppressiveness of certain soils to fungal diseases, probably by influencing microbial populations responsible for the disease-suppressive status (12). As for nematodes, the abundance of specific ectoparasites (e.g., $H$. dihystera and $X$. elongatum) can correlate with soil parameters such as $\mathrm{pH}$, $\mathrm{Na}$, or $\mathrm{Mg}(2,3,9,39)$. However, in this study, the differences in soil composition between suppressive and conducive soils often were of less magnitude than in other studies. Soil content in $\mathrm{Al}$ was higher at Compensation than at La Mercy (60 versus $32 \mathrm{ppm}$ ), and similar differences were found by Kluepfel et al. (15) for soils suppressive and conducive to the ring nematode Criconemella xenoplax (15 versus $4 \mathrm{ppm}$ ). Therefore, differences in soil properties also may have an impact on the composition of the nematode community at La Mercy and Compensation; and, indeed, both the population level of $H$. dihystera and its prevalence among ectoparasites were positively correlated with organic matter (as found in Caribbean sugarcane fields; 3) and calcium contents, and were negatively correlated with $\mathrm{pH}$ (Table 3). Thus, it appears that La Mercy and Compensation displayed the same type of soil at first sight; however, when analyzed in more detail, differences in soil composition were found that perhaps explain, directly or indirectly (i.e., via biotic factors), the differences in the composition of the nematode community.

La Mercy and Compensation are located in the same climatic area of Kwazulu Natal, but it was not known whether meaningful microclimatic differences existed between the two sites. The mesocosm greenhouse experiment was set up in an effort to address this issue. Based on the results obtained, it appears that particular microclimatic conditions probably were not an important factor in the predominance of $H$. dihystera at Compensation. The mesocosm greenhouse experiment carried out with plant cane also was useful in that sugarcane (a perennial grass) needs more frequent replanting at La Mercy. This is due to nematode attacks and, thus, the ratoon cane usually is younger than at Compensation (although the difference in the age of the crop was only 1 year in the current work), a possible source of bias when comparing both sites in situ. In this context, we could not show that the differences between nematode communities translated into statistically significant differences in root development, because fluctuation of data was high.

The size of the bacterial community in rhizosphere soil was similar at Compensation and La Mercy, regardless of whether the total number of bacterial cells present or the total number of culturable aerobic bacteria was considered (Table 5). The genetic structure of the community was determined in order to investigate whether the difference in the structure of the nematode community correlated with differences in the bacterial community. RISA was previously successful in documenting the impact of mercury on indigenous bacteria present within different soil microenvironments (23) and that of trifolitoxin production by inoculated Rhizobium etli on rhizosphere bacterial community (27), as well as in identifying indigenous bacterial populations favored (22) or negatively affected by the impact (27). In the current work, automated RISA allowed us to detect differences between the two sites, but PCA ordination did not differentiate them fully. In a previous work, we observed that bacterial communities in soils from different geographic locations with contrasting vegetation cover and pedoclimatic properties were each characterized by a very specific automated RISA profile (25). Therefore, the lack of a clear distinction between La Mercy and Compensation may be explained by the fact that the differences regarding their soil characteristics were small.

The difference in the bacterial community at Compensation and La Mercy can be illustrated in the case of the culturable fluorescent Pseudomonas spp., whose population level was statistically higher at La Mercy than at Compensation, both in the field (Table 5) and in mesocosms (data not shown). Fluorescent pseudomonads can have positive and negative effects on phytoparasitic nematodes $(7,12,15)$, and further work will be needed to assess their role in the current situation. Population levels recorded here were not very high $(16,20,21)$, and perhaps the higher value at $\mathrm{La}$ Mercy is a consequence of nematode attacks, because the latter are likely to increase rhizodeposition $(21,40)$ and pseudomonads are well adapted to colonization of damaged roots $(20,40)$. Whether this difference in the level of fluorescent pseudomonads is detectable by RISA has not been assessed but could be investigated by hybridizing Pseudomonas-specific intergenic probes toward RISA profiles or performing RISA after defining Pseudomonas-specific primers.

In addition to fluorescent pseudomonads, it is possible that the two sites also differed when considering other bacterial populations capable of influencing nematodes via parasitism (e.g., targeting Pratylenchus zeae species) (31), toxin- $(18,30)$ or lytic enzymemediated (6) antagonism, catabolism of root exudate compounds that control nematode behavior (31), or induced systemic plant resistance (14). Here, counts of putative culturable Burkholderia spp. were the same at both sites, but strains of Burkholderia spp. can differ in their ability to affect nematodes (18) and it may be useful in further work to assess the species or intraspecific diversity of this taxon. Furthermore, nonphytopathogenic fungi (e.g., fungal hyperparasites) (14) or members of the soil fauna other than nematodes (8) can play a role in the biocontrol of nematode attacks, and whether they are of any significance at La Mercy and Compensation is unknown. The microbial basis of disease suppressiveness often is investigated by assessing the consequences of antimicrobial treatments or the addition of small amounts of suppressive soil to conducive or fumigated suppressive soil $(15,42)$ and, in further work, it will be of interest to implement these approaches with Compensation and La Mercy soils.

In conclusion, the sandy soils at La Mercy and Compensation exhibited a number of apparently small differences, which nevertheless may account for the differences observed in terms of ectoparasitic nematodes and, thus, nematode damage to sugarcane. Whether the seemingly modest differences in the bacterial community are also implicated in or merely a consequence of the contrasted crop health remains to be assessed.

\section{ACKNOWLEDGMENTS}

We thank D. Largeron (UMR CNRS 5557, Lyon1) for technical help; and R. Duponnois (IRD), J. Thioulouse (UMR CNRS 5558, Lyon1), L. Jocteur Monrozier, J. Balandreau, R. Bally, and P. Normand (UMR CNRS 5557, Lyon1) for useful discussions.

\section{LITERATURE CITED}

1. Cadet, P., and Spaull, V. W. 1985. Studies on the relationship between nematodes and sugarcane in south and west Africa: Plant cane. Rev. Nématol. 8:277-284. 
2. Cadet, P., and Thioulouse, J. 1998. Identification of soil factors that relate to plant parasitic nematode communities on tomato and yam in the French West Indies. Appl. Soil Ecol. 8:35-49.

3. Cadet, P., Thioulouse, J., and Albrecht, A. 1994. Relationships between ferisol properties and the structure of plant parasitic nematode communities on sugarcane in Martinique (French West Indies). Acta Oecol. 15:767-780.

4. Chen, Z. X., and Dickson, D. W. 1998. Review of Pasteuria penetrans: Biology, ecology, and biological control potential. J. Nematol. 30:313340.

5. Cook, R. J., and Baker, K. F. 1983. The Nature and Practice of Biological Control of Plant Pathogens. The American Phytopathological Society, St. Paul, MN.

6. Cronin, D., Moënne-Loccoz, Y., Dunne, C., and O'Gara, F. 1997. Inhibition of egg hatch of the potato cyst nematode Globodera rostochiensis by chitinase-producing bacteria. Eur. J. Plant Pathol. 103:433-440.

7. Cronin, D., Moënne-Loccoz, Y., Fenton, A., Dunne, C., Dowling, D. N., and O'Gara, F. 1997. Role of 2,4-diacetylphloroglucinol in the interactions of the biocontrol pseudomonad F113 with the potato cyst nematode Globodera rostochiensis. Appl. Environ. Microbiol. 63:1357-1361.

8. Curl, E. A. 1988. The role of soil microfauna in plant-disease suppression. CRC Crit. Rev. Plant Sci. 7:175-196.

9. Delaville, L., Rossi, J. P., and Quénéhervé, P. 1996. Plant row and soil factors influencing the microspatial patterns of plant-parasitic nematodes on sugarcane in Martinique. Fundam. Appl. Nematol. 19:321-328.

10. Dickson, D. W., Mitchell, D. J., Hewlett, T. E., Oostendorp, M., and Kannwischer-Mitchell, M. E. 1991. Nematode suppressive soil from a peanut field. (Abstr.) J. Nematol. 23:526.

11. Gould, W. D., Hagedorn, C., Bardinelli, T. R., and Zablotowicz, R. M. 1985. New selective media for enumeration and recovery of fluorescent pseudomonads from various habitats. Appl. Environ. Microbiol. 49:2832.

12. Hoeper, H., and Alabouvette, C. 1996. Importance of physical and chemical soil properties in the suppressiveness of soils to plant diseases. Eur. J. Soil Biol. 32:41-58.

13. Kenkel, N. C., and Booth, T. 1992. Multivariate analysis in fungal ecology. Pages 209-227 in: The Fungal Community: Its Organization and Role in the Ecosystem. D. T. Wicklow and G. C. Carroll, eds. Marcel Dekker, New York.

14. Kerry, B. R. 2000. Rhizosphere interactions and the exploitation of microbial agents for the biological control of plant-parasitic nematodes. Annu. Rev. Phytopathol. 38:423-441.

15. Kluepfel, D. A., McInnis, T. M., and Zehr, E. I. 1993. Involvement of root-colonizing bacteria in peach orchard soils suppressive of the nematode Criconemella xenoplax. Phytopathology 83:1240-1245.

16. Moënne-Loccoz, Y., Tichy, H. V., O’Donnell, A., Simon, R., and O'Gara, F. 2001. Impact of 2,4-diacetylphloroglucinol-producing biocontrol strain Pseudomonas fluorescens F113 on intraspecific diversity of resident culturable fluorescent pseudomonads associated with the roots of field-grown sugar beet seedlings. Appl. Environ. Microbiol. 67:34183425 .

17. Normand, P., Ponsonnet, C., Nesme, X., Neyra, M., and Simonet, P. 1996. ITS analysis of prokaryotes. Pages 1-12 in: Molecular Microbial Ecology Manual. D. L. Akkermans, J. D. van Elsas, and F. J. de Bruijn, eds. Kluwer Academic Publishers, Dordrecht, The Netherlands.

18. O'Quinn, A. L., Wiegand, E. M., and Jeddeloh, J. A. 2001. Burkholderia pseudomallei kills the nematode Caenorhabditis elegans using an endotoxin-mediated paralysis. Cell Microbiol. 3:381-393.

19. Pallud, C., Viallard, V., Balandreau, J., Normand, P., and Grundmann, G. L. 2001. Combined use of a specific probe and PCAT medium to study Burkholderia in soil. J. Microbiol. Methods 47:25-34.

20. Raaijmakers, J. M., Bonsall, R. F., and Weller, D. M. 1999. Effect of population density of Pseudomonas fluorescens on production of 2,4diacetylphloroglucinol in the rhizosphere of wheat. Phytopathology 89:470-475.

21. Ramette, A., Moënne-Loccoz, Y., and Défago, G. 2003. Prevalence of fluorescent pseudomonads producing antifungal phloroglucinols and/or hydrogen cyanide in soils naturally suppressive or conducive to tobacco black root rot. FEMS Microbiol. Ecol. 44:35-43.

22. Ranjard, L., Brothier, E., and Nazaret, S. 2000. Sequencing bands of ribosomal intergenic spacer analysis fingerprints for characterization and microscale distribution of soil bacterial populations responding to mercury spiking. Appl. Environ. Microbiol. 66:5334-5339.
23. Ranjard, L., Nazaret, S., Gourbière, F., Thioulouse, J., Linet, J., and Richaume, A. 2000. A soil microscale study to reveal the heterogeneity of $\mathrm{Hg}$ (II) impact on indigenous bacteria by quantification of adapted phenotypes and analysis of community DNA fingerprints. FEMS Microbiol. Ecol. 31:107-115.

24. Ranjard, L., Poly, F., Combrisson, J., Richaume, A., and Nazaret, S. 1998. A single procedure to recover DNA from the surface or inside aggregates and in various size fractions of soil suitable for PCR-based assays of bacterial communities. Eur. J. Soil Biol. 34:89-97.

25. Ranjard, L., Poly, F., Lata, J.-C., Mougel, C., Thioulouse, J., and Nazaret, S. 2001. Characterization of bacterial and fungal soil communities by automated Ribosomal Intergenic Spacer Analysis fingerprints: Biological and methodological variability. Appl. Environ. Microbiol. 67:4479-4487

26. Richaume, A., Steinberg, C., Jocteur Monrozier, L., and Faurie, G. 1993. Differences between direct and indirect enumeration of soil bacteria: The influence of soil structure and cell location. Soil Biol. Biochem. 25:641643.

27. Robleto, E. A., Borneman, J., and Triplett, E. 1998. Effects of bacterial antibiotic production on rhizosphere microbial communities from a culture-independent perspective. Appl. Environ. Microbiol. 64:5020-5022.

28. Roth, G. 1971. The effects of filtercake on soil fertility and yield of sugarcane. Proc. S. Afr. Sugar Technol. Assoc. 45:142-148.

29. Seinhorst, J. W. 1962. Modifications of the elutriation method for extracting nematodes from soil. Nematologica 8:117-128.

30. Sharma, R. D., and Gomes, A. C. 1996. Effects of Bacillus spp. toxins on oviposition and juvenile hatching of Heterodera glycines. Nematol. Bras. 20:53-62.

31. Siddiqui, Z. A., and Mahmood, I. 1999. Role of bacteria in the management of plant parasitic nematodes: A review. Bioresour. Technol. 69:167-179.

32. Spaull, V. W., and Cadet, P. 1990. Nematodes parasites of sugarcane. Pages 461-491 in: Plant Parasitic Nematodes in Subtropical and Tropical Agriculture. M. Luc, R. A. Sikora, and J. Bridge, eds. CAB International, Wallingford, UK.

33. Spaull, V. W., and Cadet, P. 1991. Studies on the relationship between nematodes and sugarcane in south and west Africa: Ratoon cane. Rev. Nématol. 14:183-186.

34. Stirling, G., and Blair, B. 2000. Nematodes. Pages 299-305 in: A Guide to Sugarcane Diseases. P. Rott, R. A. Bailey, J. C. Comstock, B. J. Croft, and A. S. Saumtally, eds. CIRAD, ISSCT, Montpellier, France.

35. Stirling, G. R., McKenry, M. V., and Mankau, R. 1979. Biological control of root-knot nematodes (Meloidogyne spp.) on peach. Phytopathology 69:806-809.

36. Stutz, E., Défago, G., and Kern, H. 1986. Naturally occurring fluorescent pseudomonads involved in suppression of black root rot of tobacco. Phytopathology 76:181-185.

37. Thioulouse, J., Chessel, D., Dolédec, S., and Olivier, J. M. 1997. ADE-4: A multivariate analysis and graphical display software. Stat. Comput. 7:75-83.

38. Thomashow, L. S., and Weller, D. M. 1996. Current concepts in the use of introduced bacteria for biological disease control: Mechanisms and antifungal metabolites. Pages 187-235 in: Plant-Microbe Interactions, Vol. 1. G. Stacey and N. Keen, eds. Chapman \& Hall, New York.

39. Trevathan, L. E., Cuarezma-Teran, J. A., and Gourley, L. M. 1985. Relationship of plant-nematodes and edaphic factors in Colombian grain sorghum production. Nematropica 15:145-153.

40. Troxler, J., Zala, M., Natsch, A., Moënne-Loccoz, Y., and Défago, G. 1997. Autecology of the biocontrol strain Pseudomonas fluorescens CHA0 in the rhizosphere and inside roots at later stages of plant development. FEMS Microbiol. Ecol. 23:119-130.

41. Villenave, C., and Cadet, P. 1998. Interactions of Helicotylenchus dihystera, Pratylenchus sefaensis and Tylenchorhynchus gladiolatus on two plants from the soudano-sahelian zone of West Africa. Nematropica 28:31-39.

42. Westphal, A., and Becker, J. O. 2000. Transfer of biological soil suppressiveness against Heterodera schachtii. Phytopathology 90:401406.

43. Yeates, G. W. 1999. Effects of plants on nematode community structure. Annu. Rev. Phytopathol. 37:127-149.

44. Zuckerman, B. M., Dicklow, M. B., Coles, G. C., Garcia, E. R., and Marban-Mendoza, N. 1989. Suppression of plant parasitic nematodes in Chinampa agricultural soils. J. Chem. Ecol. 15:1947-1955. 